\title{
Community Views About Zakat on Cryptocurrencies
}

\author{
Muhsin Nor Paizin \\ Akademi Zakat, Pusat Pungutan Zakat, Malaysia \\ e-mail: muhsin.paizin@zakat.com.my / muhsin.paizin@gmail.com
}

\begin{abstract}
Abstrak
The cryptocurrency industry has exploded, with an increasing number of individuals investing in digital assets - even Malaysians who adhere to Shariah financial norms. The surge in Islamic faith members' involvement in cryptocurrencies such as Bitcoin and Ethereum has given birth to Zakat payments. Zakat is the third pillar of Islam, and it compels Muslims to make charitable contributions if they have sufficient means. The major considerations to explore are whether zakat is required on cryptocurrency investments and how the community sees zakat on cryptocurrencies. As a result, this paper will investigate the prospect of cryptocurrencies as a digital assets being a new source of revenue for zakat from an Islamic perspective by acquiring appropriate rulings (fatwas) and then investigating community attitudes on zakat on cryptocurrency..
\end{abstract}

Keywords: —zakat cryptocurrency, digital asset, cryptocurrency, new source of zakat, zakat management

\section{INTRODUCTION}

Digital currencies, such as Bitcoin, have recently garnered a lot of popularity, and they serve the same purpose as fiat currency except that they do not exist in physical form. From an Islamic perspective, academics and jurists disagree on whether digital currencies count as 'māl' in which case they are entitled for zakat. As a result, this study will investigate the possibilities of digital assets serving as a new source of revenue for zakat from an Islamic perspective, as well as the community's perspectives on zakat on cryptocurrencies. Finally, this research will give comments and recommendations on the influence on zakat collection.

\section{LITERATURE REVIEW}

\section{Shariah perspective on cryptocurrencies}

A cryptocurrency is a sort of virtual currency that uses encryption to verify that anyone seeking to use it is genuine. Cryptocurrencies often employ a decentralised peer-topeer network (also known as a blockchain) to verify and record transactions on a decentralised public ledger. Owners of bitcoin, for example, desire to purchase things from merchants who accept cryptocurrency as payment. The currency is transmitted utilising the public ledger system rather than a bank. To distinguish the many sorts of tokens or coins 
that have been minted, several labels have been employed. For example, Bitcoin, the most well-known cryptocurrency, was first introduced by Satoshi Nakamoto in a white paper published in 2008 (widely assumed to be an alias for either a single person or a group of people who collaborate). The sole function and purpose of Bitcoin is to serve as a medium of exchange. ${ }^{1}$

In general, cryptocurrency is managed by a protocol that specifies how many coins may be issued, how they are created, and how the ledger's integrity is preserved. These protocols are intended to be analogous to government regulations and laws that underpin fiat money, and their strength will influence digital currency confidence and, as a result, supply and demand. Most cryptocurrency blockchains are designed in such a way that modifying their operational protocol is difficult, if not impossible. When a cryptocurrency enters circulation, there are several methods to receive it. It may be purchased on exchanges; some people accept it because their company permits them to take digital money; some stores accept cryptocurrencies as payment for products and services; and individuals or organisations who maintain the bitcoin blockchain are often rewarded with cryptocurrency. $^{2}$

\section{Legal Criterion of Property (Māl) In Islam}

In Shariah, the most important aspect of a counter value or consideration is that it has the status of māl, which signifies property. As a result, before discussing the status of cryptocurrencies, it is critical to understand the notion of mâl in Shariah. When it comes to the notion of property in Islam, scholars have differing viewpoints. ${ }^{3}$ Ibn Abidin of the Hanafi school of thought defined property as anything wanted and capable of being kept for future use. According to the Maliki school, Ibn Al-Arabi defined property as something wanted, and its usufruct is both customary and legally valid. It is something that is typically helpful, according to Hanabilah. Property, according to al-Zarka of the Shafie school, is defined as something helpful or ready to be profited from. According to the majority of Islamic scholars, māl refers to something valuable that may be exchanged and must be compensated for anybody who damages it. ${ }^{4}$ Apart from being useful and possessable, it is necessary to have two critical characteristics in order to be considered property in Islam: mutaqawwam (permissible and lawful in Shariah) and customary consideration ('urf).

i. Mutaqawwam. This is a necessary condition for classifying something as māl. Something that is allowable in Shariah is called mutaqawwam. The mutaqawwam is defined by Ibn Ābidīn as "something that is stored or present and permissible to use". So, if it is not saved or present, it is not considered māl. For that reason, if

\footnotetext{
${ }^{1}$ Norton Rose Fulbright. (2015). "Deciphering cryptocurrencies: A global legal and regulatory guide." In Chapter 1: Introduction to cryptocurrencies, 1- 20.

2 Dodik Siswantoro, Handika Rangga, and Aria Farah Mita. (2020). "The requirements of cryptocurrency for money, an Islamic view," Heliyon, 6(1), e03235. https://doi.org/10.1016/j.heliyon.2020.e03235

${ }^{3}$ Al-Auqof Al Kuwaitiyah. (1983) "al-Islamiyyah, al-Mausu'ah al-Fiqhiyah al-Kuwaitiyah." Kuwait: Dzat as-Salasil.

${ }^{4}$ Al-Suyuti, Jalaulddin. (1983). "Al-Ashbah wa al-Naza'ir." Kairo: Dar al-Salâm (1983).

${ }^{5}$ Abidin, I. (1992). Radd al-Muhtār 'ala al-Dar al-Mukhtār. Dar al-Fikr.
} 
something is not lawful and permissible in Shariah, it could not be regarded as māl, such as dead animals, swine, and alcohol. However, it is important to note that according to the majority of the scholars (Shafie, Māliki and Hanbali), Mutaqawwam is not one of elements of māl, rather if something is not allowable to benefit from in Shariah, it is not considered as māl of any kind. ${ }^{6}$

ii. 'Urf. In the absence of specific decisions or judgments from Shariah scriptures (AlQuran and Sunnah), customary practise plays an essential role. According to the jurists, what is drawn from urf is identical to what is derived from the scriptures. In the issue of property, the definition and criterion are not explicitly established in Shariah scriptures. As a result, researchers believe that the importance of custom in deciding property is highlighted in this way. All four schools of Islamic law's jurists agree that if anything becomes valued because to people's custom and acceptance, it is deemed acceptable.

\section{Recognization of Digital Currency as Māl (property) from Shariah Perspective}

Digital money is suitable and qualifies for consideration as mâl. This is due to the fact that digital currency is advantageous and, moreover, seen as valued by the general public. The decision is consistent with the Shariah Advisory Council's resolution, which stipulates that digital currency is deemed legitimate from a Shariah standpoint. From an Islamic perspective, the usage of cryptocurrencies as a medium of trade is an intriguing issue. This is due to the fact that cryptocurrency in the financial system is built on cryptography. The blockchain system's algorithm is also utilised to compute the value of cryptocurrencies. To satisfy the requirements of an instrument of trade or money in Islamic principles, money must be stable, secure, and efficient. Cryptocurrency may have certain money-like properties, but more research is needed to understand what these "money" properties are.

Economists believe that currency has three conditions. Whenever available, it is considered currency; i) Medium of exchange; ii) Unit of value; and iii) Store of value. Money can be everything which is used as a medium of exchange - whether it is gold, silver, flower petals, skin, paper, etc. - if it is generally accepted among the people. ${ }^{8}$ The jurists and scholars have classified money into two types: ${ }^{9}$

i. Natural money. Natural money is a type of money that was created to serve as a means of exchange and to have monetary worth. Natural money is something that is produced intentionally to operate as money and a means of exchange, as opposed to something that is awarded that status via people's usual practise and acceptance.

\footnotetext{
${ }^{6}$ Al-Auqof Al Kuwaitiyah. (1983) "al-Islamiyyah, al-Mausu'ah al-Fiqhiyah al-Kuwaitiyah." Kuwait: Dzat as-Salasil.

${ }^{7}$ Abu-Bakar, Mufti Muhammad. (2017). "Shariah Analysis of Bitcoin, Cryptocurrency and Blockchain."

${ }^{8}$ Al-Auqof Al Kuwaitiyah. (1983) "al-Islamiyyah, al-Mausu'ah al-Fiqhiyah al-Kuwaitiyah." Kuwait: Dzat as-Salasil.

${ }^{9}$ Abu-Bakar, Mufti Muhammad. (2017). "Shariah Analysis of Bitcoin, Cryptocurrency and Blockchain."
} 
Gold and silver are natural money in whatever shape they take since they were created to be used as money and a means of payment. According to the eminent jurist Imam al-Ghazali, Allah SWT created gold and silver so that they may be disseminated and used as units of measurement for various attributes. Gold and silver are important because they are utilised to acquire all other assets; they are desired not for their own sake, but as a means of acquiring other things. ${ }^{10}$

ii. Customary Money. Customary money is a type of money that has gained currency status as a result of people's acceptance of it. While customary money was not created to serve as a medium of commerce, it is widely recognised. Common kinds of customary currency include commodities (other than gold and silver) and fiat currencies. Usual money does not have inherent moneyness (thamniyyah); rather, it is assigned moneyness by its customary user. Natural money is money by definition and does not require any sort of acknowledgment, whereas conventional money does. Customary money is further subdivided into commodity money and fiat money. Commodity money has inherent worth and may be utilised for other things, but it lacks intrinsic moneyness. Fiat money is paper currency created by governments that has neither intrinsic value nor intrinsic moneyness. ${ }^{11}$

\section{Whether Digital Assets is classified as currency or goods?}

According to the facts and opinions obtained, digital assets are still classified as commodities (financial assets) and are not yet eligible to become a currency. This is due to the fact that in order to qualify as a currency, it must meet certain requirements, which digital assets do not meet. According to the facts and opinions obtained, digital assets are still classified as commodities (financial assets) and are not yet eligible to become a currency. This is due to the fact that in order to qualify as a currency, it must meet certain requirements, which digital assets do not meet. The criteria to qualify are as follows; i) Māl (treated as valuable things); ii) Accepted and approved as a medium of exchange by all or significant group of people; and iii) Thamaniyyah: - independent standard of value and unit of account.

The current state of Bitcoin is that it is not a stand-alone indication of value. Bitcoin's value is still determined by the value of fiat currencies. Thamaniyyah insists on a clear value reference for the money. Bitcoin is insufficient as a stand-alone store of value. Furthermore, for anything to be an independent standard of worth, it must be stable and widely accepted. The volatility and instability of Bitcoin go counter to the very purpose of currency, which is to safeguard and balance our daily lives. Bitcoin's key position and characteristic have been lost as a result of the uncertainty and volatility. ${ }^{12}$ Thamaniyyah's second function is to act as a unit of account. This is true for those who use it as a primary

\footnotetext{
${ }^{10}$ Al-Ghazali. (2004). Ihya 'Ulum al-Din. Dar al-Marifah.

${ }^{11}$ Abu-Bakar, Mufti Muhammad. (2017). "Shariah Analysis of Bitcoin, Cryptocurrency and Blockchain."

12 Adam, Mufti Faraz. (2017). "Bitcoin: shariah compliant." Amanah Finance Consultancy 2017 (2017): 1-

54. http://www.iefpedia.com/english/wp-content/uploads/2017/12/Bitcoin-Shariah-Compliant-Mufti-FarazAdam.pdf
} 
reference point and yardstick when posting rates and keeping track of obligations. It is the unit of measurement used to determine the worth of products and services.

\section{Zakat on Cryptocurrencies}

If, based on the facts and opinions acquired, digital money is to be deemed a commodity or financial asset rather than currency, it is necessary to do study on the zakat rule to determine whether it may be imposed on digital currency or not. To that end, this section will go through the essential aspects of zakat before delving into the zakat judgement for digital money. Zakat, also known as mandatory charity, is a type of duty that every Muslim is required to fulfil according to the fifth pillar of Islam. It is a religious responsibility for Muslims who satisfy the required parameters of a common minimum amount (nisab) and a one-year term (haul) to contribute 2.5 percent of their wealth to eight categories of particular recipients each year. Muslims are exempt from paying zakat if their wealth is less than a certain level known as the nisab. ${ }^{13}$

Apart from that, zakat is not only a spiritual obligation, but also an important component of the Islamic social assistance system. The zakat acts as a kind of wealth redistribution, benefiting the whole community, particularly those who have been designated as specific beneficiaries. The responsibility for Muslims to pay zakat is drawn primarily from the Quran, while the details on which types of wealth are due for zakat, circumstances, and how much percentage should be deducted for zakat are obtained mostly from hadith Rasulullah SAW. As a result, before considering zakat, it is critical to grasp the requirements of zakat as well as the factors buried within it. ${ }^{14}$

Zakat is divided into two types: zakat fitrah and zakat harta or wealth. Instead of zakat fitrah, the debate will centre on zakat on wealth. Zakat on wealth is classified into numerous sorts or categories, including zakat on earnings or income, zakat on business, zakat on savings, zakat on gold and silver, zakat on farming, and zakat on animals. ${ }^{15}$ As a result, the question of whether digital money fits within the classification of wealth that can be subjected to zakat has emerged. To that end, we must investigate its character in order to determine the right zakat decision. The differing views on the permissibility of digital currency have influenced views on the zakat regulation that can be applied on such currency. Despite the fact that digital currency is an intangible, it has values that can be transferred, distributed, and exchanged. Furthermore, ownership may be transferred from one person to another (peer to peer) without the need for any intermediaries like as financial organisations or banks.

Looking at the nature of such currency (from prior discussion on digital currency), there is a need to infer the zakat judgement on digital currency in this circumstance. In general, classifying digital money as a commodity is regarded suitable due to its nature as

\footnotetext{
${ }^{13}$ MN Paizin. (2014). Perlaksanaan Zakat Di Wilayah Persekutuan: Satu Pemerhatian Terhadap Operasi Kutipan \& Agihan Zakat. Jurnal Hadhari: An International Journal 6 (2), 97-111

${ }^{14}$ MN Paizin. (2017). Usage of Islamic Alms's Online Portal: Case Study on Pusat Pungutan Zakat (PPZ), Federal Territories of Malaysia. Intellectual Property Rights: Open Access, Vol.5, Issue.1 :3.

${ }^{15}$ MN Paizin. (2017). Usage of Islamic Alms's Online Portal: Case Study on Pusat Pungutan Zakat (PPZ), Federal Territories of Malaysia. Intellectual Property Rights: Open Access, Vol.5, Issue.1 :3.
} 
well as its status as a new financial instrument. It is then regarded as a commodity with nearly identical characteristics and functions as money. However, Shariah scholars offer a few circumstances when imposing zakat on commodities, which include: ${ }^{16}$

i. The reasons for paying zakat from it is due to the purpose of selling and buying of it.

ii. The commodity acquired resulted from the transaction of buying and selling.

iii. The intention to sell the commodity once the commodity has been acquired. This also subjected to those who buy the commodity for his own uses but then decided to sell after the price increases, such act also considered as intention to sell.

iv. Fulfill the nisab requirement where the minimum amount is benchmarking on the value of gold or silver.

v. Fulfill the haul requirement where the owner own such assets for one completed owning year.

vi. The commodity is being valued according to the market value. To that the zakat then will be calculated when the market value fulfilled the nisab requirements.

According to Malaysian law, the power to collect and distribute zakat is vested in the state. The task is carried out by the State Islamic Religious Council (SIRC) or Majlis Agama Islam Negeri (MAIN). As a result, any fatwa concerning zakat falls under the scope of the aforementioned authorities. ${ }^{17}$ To now, the SIRC of Perlis is the only state to have released a formal declaration regarding Bitcoin zakat. In 2020, the Fatwa Committee of Perlis formally announced that Bitcoin (one of the digital currencies) can be subject to zakat if it meets the haul and nisab requirements for being classified as a commodity.

Some digital currencies have been released with a specific underlying asset on them, while others have been issued to carry out a specific project or for a specific purpose. As a result, the underlying assets for the digital currency or the reason for its issue decide whether or not zakat can be imposed on it. For example, if a digital currency reflects gold as one of its fundamental assets, it is subject to the zakat law on gold. Apart from that, he stated that such issuance of digital currency must be in accordance with Shariah in order for zakat to be imposed on it, as if the issuance is for some non-shariah compliant purpose or with a non-shariah compliant underlying asset, this digital currency will automatically lose its valuable (mutaqawwam) elements in Shariah and will no longer be deemed as valid financial assets according to Shariah.

However, because to its absence of many pillars as money or currency, digital currency may be classified as a commodity or financial asset rather than a currency. He then went on to say that, as a commodity, digital currency is exempt from zakat. However, if the owners who engage in digital currency trading and make a profit from the trading want to pay zakat, he proposed that the action be carried out by enforcing the zakat regulation on savings in such situations. To that end, my research on the subject is based on the belief that such digital money is liable to zakat. This is owing to the fact that digital

\footnotetext{
16 Abd Rahman, Ahmad Husni and Abdullah, Muhammad Furqan. (2021). Tinjauan Awal Aplikasi Hukum Zakat Ke Atas Matawang Kripto Dan Token Digital. Pusat Pungutan Zakat

${ }^{17}$ MN Paizin. (2021). The Concept of Zakat on Income in Malaysia and Its Beginning of Implementation. AlKharaj: Jurnal Ekonomi, Keuangan \& Bisnis Syariah 3 (3), 417-436
} 
currency trading creates a profit for its owners. This makes it a zakatable asset since it meets the criteria of growth (al-nama'). Aside from that, it has been regarded as a commodity or financial asset due to its value and features. As a result, trading in such a product that can give a return has rendered it eligible to be subject to zakat. However, while we choose to believe that zakat can be imposed on digital currency in our study, more research is needed to establish that the imposition of zakat on digital currency is due to its functions and qualities that satisfy the criteria of wealth that are liable for zakat. This is to avoid a situation in which such assets are imposed with zakat just to boost zakat collection. ${ }^{18}$

\section{METHODOLOGY}

This survey was done to examine popular attitude and awareness of cryptocurrencies, as well as the public's willingness to pay zakat on cryptocurrencies. A total of 468 replies were obtained from the survey. In summary, it was discovered that the general public continues to question the verdict on cryptocurrency transactions. It was also discovered that 100 out of 468 respondents have spent on cryptocurrencies, implying that the penetration among Muslims is around 21\%, which is deemed low. According to the survey, the majority of them are trading in cryptocurrencies for the purpose of investing, and the reason for trading is to have the potential to earn more money through cryptocurrencies. In terms of frequency, people that trade cryptocurrencies only do it a few times to test the market. Only 30.34 percent of respondents who are entirely Muslim are going to invest in cryptocurrencies, while the remainder are still unsure and have no plans to participate in cryptocurrencies.

This survey is possibly the first of its type in Malaysia on the subject of cryptocurrency and its relationship to zakat. The purpose of this research is to investigate the factors that impact cryptocurrency acceptability among Malaysians in the Wilayah Persekutuan Kuala Lumpur region. This study employs a quantitative deductive method using an online survey questionnaire. The survey had 468 responses, which is an excellent response rate considering the survey was only open for roughly 2-3 weeks. The survey was done in both English and Bahasa Melayu, using straightforward language. The questionnaire includes both open-ended and closed-ended questions. Open-ended questions were posed to investigate respondents' degree of awareness, relevance, and attitudes on cryptocurrencies. Close-ended questions were also posed in the same areas of questions, but with alternatives for responders to pick from.

The survey is divided into four sections, the first of which asked respondents about their demographic characteristics. The second portion focused on bitcoin knowledge and usage. The final section of the survey focused on gaining a grasp of zakat and its application to cryptocurrencies. The last section of the study asked respondents about their thoughts on the "need to make cryptocurrencies zakatable," and a video presentation describing bitcoin

\footnotetext{
${ }^{18}$ Abd Rahman, Ahmad Husni and Abdullah, Muhammad Furqan. (2021). Tinjauan Awal Aplikasi Hukum Zakat Ke Atas Matawang Kripto Dan Token Digital. Pusat Pungutan Zakat
} 
in detail was provided with them, along with a question to see whether the video presentation changed their opinions.

\section{RESULTS AND FINDINGS}

This section will give findings based on survey responses to the following openended and closed-ended questions: demographic profiles, awareness and usage of crypto currency, understanding of zakat and its relation to cryptocurrency, and thoughts and opinions on zakat and cryptocurrency.

\section{Demographic profile}

The question starts with the gender which in total of 468 respondents, 61.75 per cent are female and 38.25 per cent are male. Second, the majority age range for this questionnaire is between 31 to 40 years old which is 52.35 per cent. Then, age 21-30 which is 26.5 per cent and last but not least is between the ages of 41 to 50 which is 14.74 per cent. The rest are above 50 and below 20 .

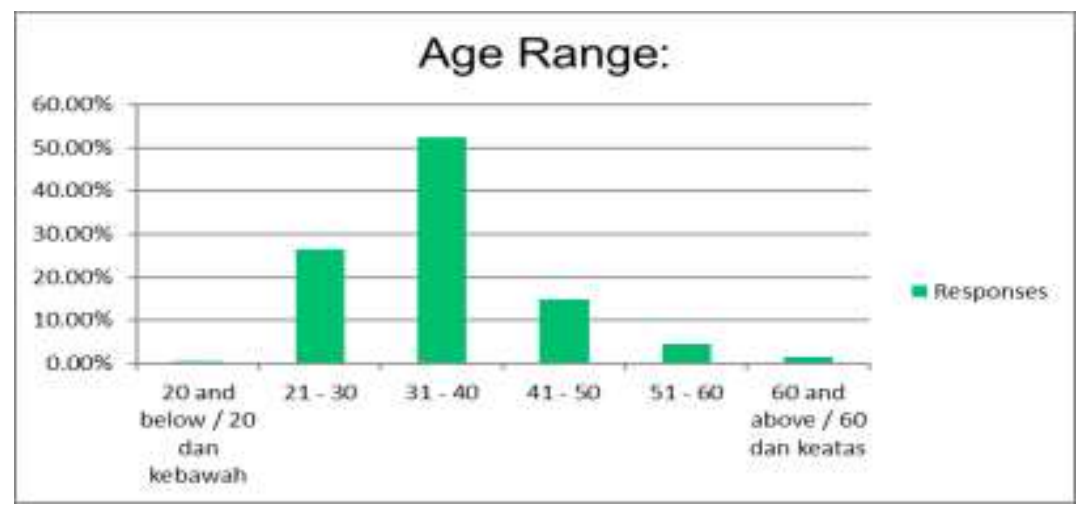

Figure 1: Age Range

Next is marital status which consist of 66.88 per cent of married, 30.13 per cent of singles and the rest are widow or divorced. After that, the location of the origin of the respondent which came majority from the zakat payer from state's zakat institution and some potential zakat payer which consist of 52.99 per cent from outside of the Kuala Lumpur, followed by the residence of Kuala Lumpur which is 45.94 per cent and the minority of 1.07 per cent is outside of Malaysia. After that, the question is about average income per month. Most of the respondent are having RM3000 to RM5000 and below per month which consist of 37.82, followed by income between RM3000 and below which consist of 28.85 per cent and then income between RM5001 to RM10,000 which consist of 24.15 per cent. Above that are minority. 


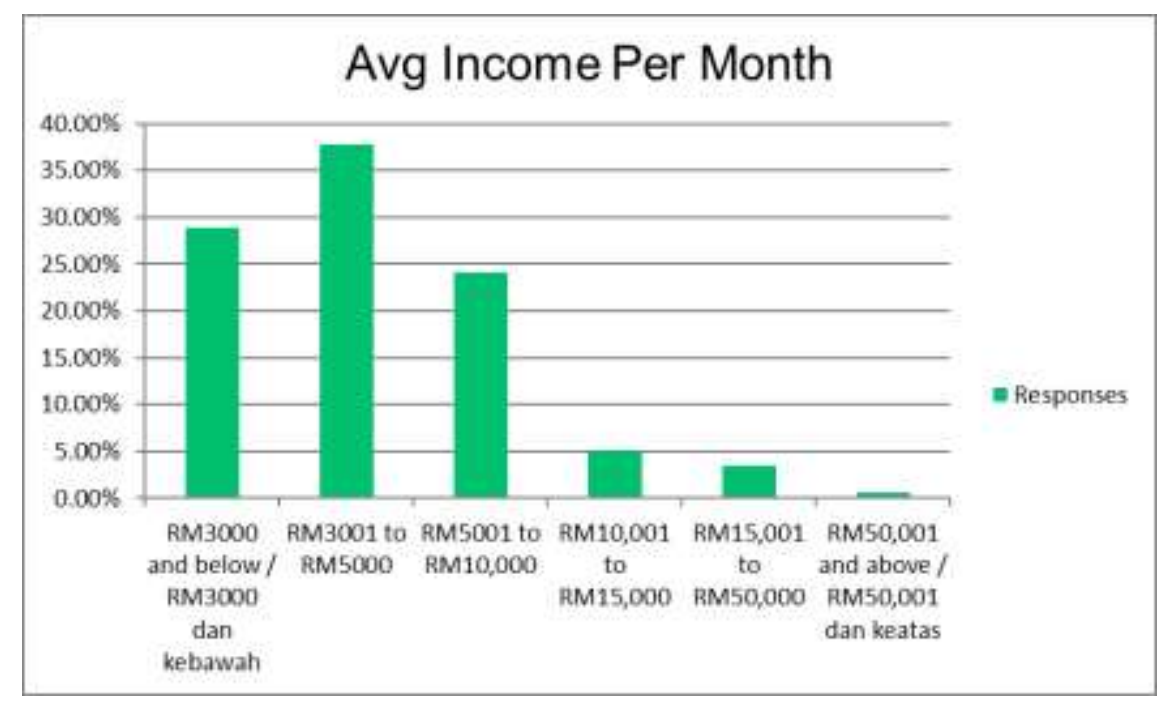

Figure 2: Average Income per Month

Last but not least is the question regarding to the occupation which is majority of it is a private employee which consist of 59.44 per cent, followed by the self-employed which is 24.68 per cent and the rest such as government, pensioner and student are minority. Indeed, gender plays an important role as the decision maker, particularly when an individual is married, as it corresponds to the marital status, but the most significant element is the level of knowledge and exposure to the subject of cryptocurrency. For this part, there are three main graphs which the zakat collector can focus on which are the age, average income per month and profession may help to recognize or to be more focus on as a target market to increase the zakat collection.

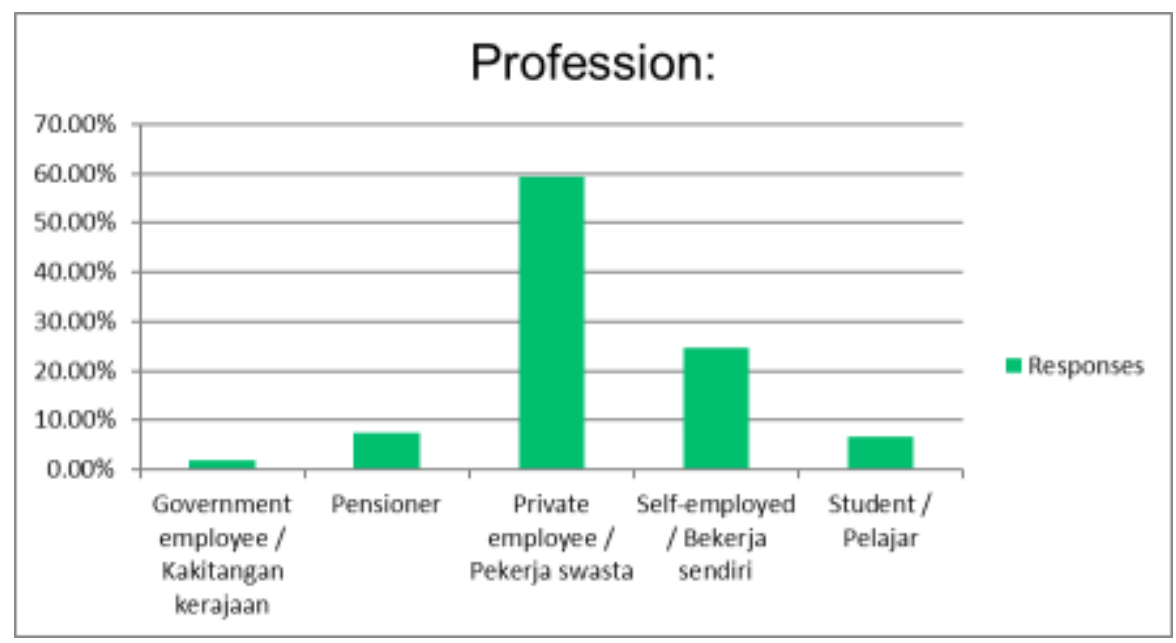

Figure 3: Profession

Figure 1 shows that the majority of those surveyed are under the age of 40 , indicating that young people and adults are concerned about this emerging cryptocurrency technology. Of course, since the salary in Figure 2 corresponds to the increase in age, the ability needs to reconsider as well to reflect the true potential of zakat payers in cryptocurrencies. People which prefer to work in private sector and as self-employed 
individuals are more risk takers and much active. Thus, what could be concluded is the zakat collectors should concentrate their efforts on young adults and adults between the ages of 20 to 40 who work in the private sector or self-employed as a good starting point for spreading knowledge about "Zakat on cryptocurrency" in order to control the majority target market.

\section{Awareness and Usage of crypto currency}

Next part of the survey concentrated on the awareness, usage and the opinions of the respondents in regard to cryptocurrency.

\section{Awareness:}

The survey showed that 90 per cent of the respondents are aware about cryptocurrency. This is in line with a survey conducted by Organization for Economic Cooperation and Development (OECD) which showed that there is a high level of awareness by Malaysians by 84 per cent in regard to cryptocurrencies compared to Philippines and Vietnam. ${ }^{19}$ However, only 21 per cent of the respondents have ever spent, or invested on cryptocurrencies. This is also similar to the survey by OECD in 2019, which showed that only 23 per cent owned crypto assets.

\section{Have you ever spent, invest or traded cryptocurrency? BEFORE VIDEO}

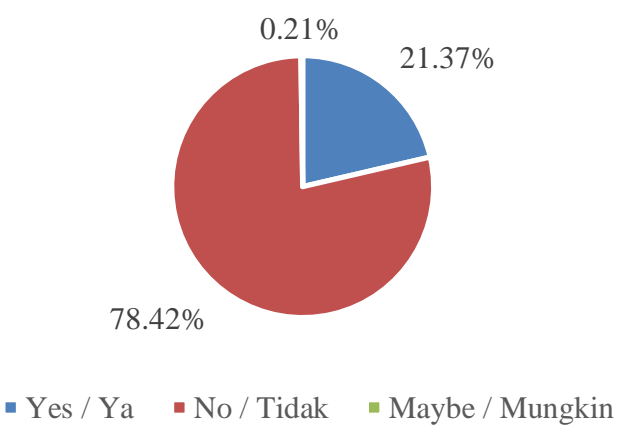

Figure 4: Respondent on Spent, Invest or Traded Cryptocurrency

Reasons for spending on cryptocurrency:

From the respondents who spent on the crypto, the main reason for buying crypto is for investment (42 per cent) and for Savings (26 per cent). The other reasons are shown below:

Table 1: Reason for Respondent to buy Cryptocurrency

\begin{tabular}{|c|c|}
\hline Why did you buy it (cryptocurrency)? & Frequency \\
\hline Investment & $42 \%$ \\
\hline Trading & $10 \%$ \\
\hline
\end{tabular}

${ }^{19}$ OECD (2019), Cryptoassets in Asia. Consumer attitudes, behaviours and experiences.

Jurnal Ilmiah Al QALAM, Vol. 15, No. 2, Juli-Desember 2021 


\begin{tabular}{|c|c|}
\hline Saving & $26 \%$ \\
\hline Trend or test market & $12 \%$ \\
\hline Others & $10 \%$ \\
\hline
\end{tabular}

This can also be seen from the next question "Why they really chose cryptocurrency?" And the main reason they chose this is to gain more income (52 per cent). While following the market trend (23.44 per cent) and transparency (14.58 per cent) and other reasons ( 9.38 per cent).

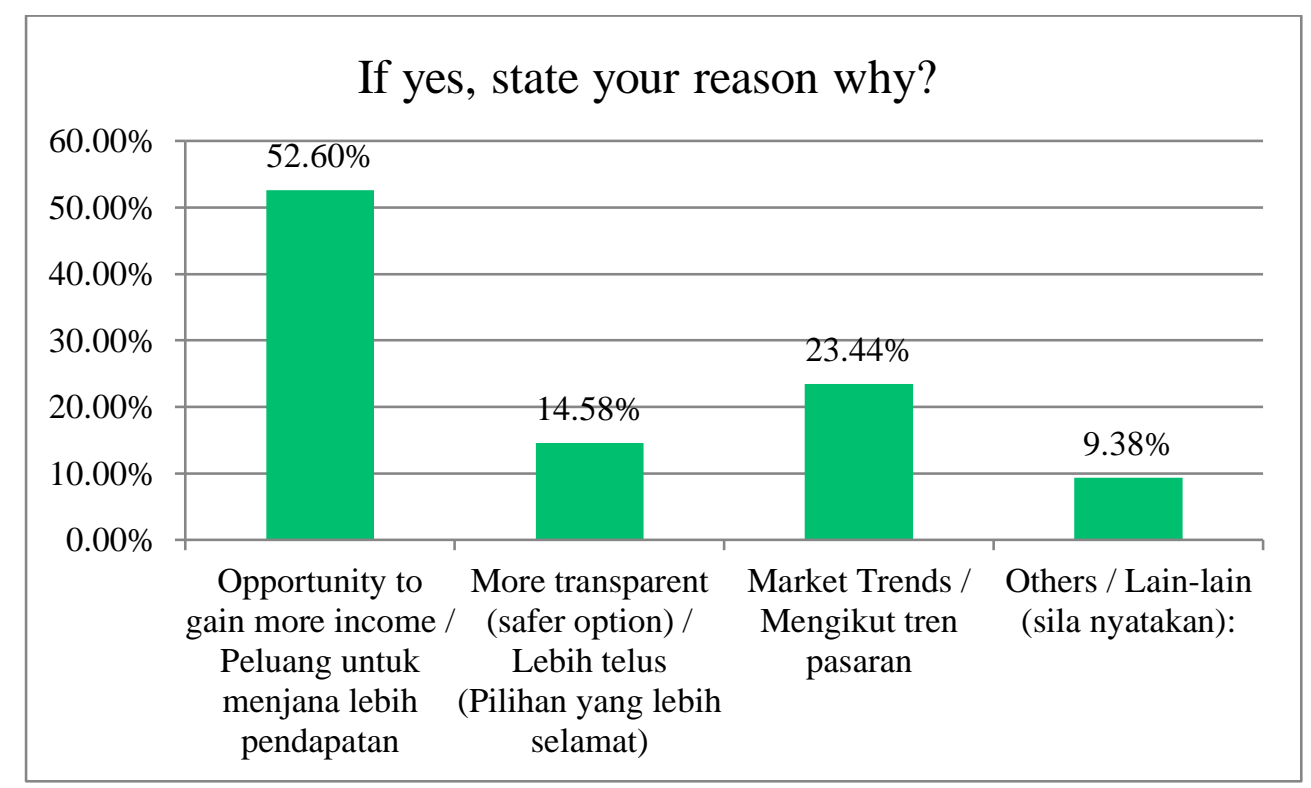

Figure 5: The reason to Spent, Invest or Traded Cryptocurrency

These results show that most cryptocurrency traders are in for investments, to increase income and to increase the savings. Zakat is generally taken from income and savings, so the scope to increase zakat collection is high. Other reasons given by respondents for investing in cryptocurrency include the desire to learn more about how cryptocurrencies function and more importantly the need to test the concept. Another reason is that the expectation of cryptocurrency as an alternative form of payment in the future. Some of the respondents claimed that they invest in cryptocurrency because they got influenced by friends to invest in cryptocurrency. While some stated due to price fluctuation in the cryptocurrency itself give a substantial profit on the price spread to the trader which enticed them to invest in cryptocurrency.

All in all, it can be seen that most of the reason for the respondents to invest in cryptocurrency is because they want to learn on how the cryptocurrency really works in the platform. The reason is valid since cryptocurrency in Malaysia itself is still in early stage, and so people get curious and they started to invest in it for learning purposes.

\section{Money spent on cryptocurrency}

In terms of the amount of money spent on cryptocurrency not much is spent by the respondents. It shows that 57 per cent spent less than RM1000 and 2.7 per cent spent more 
than RM5001. The frequency of the 21 per cent who spent on cryptocurrency are shown from the following graph.

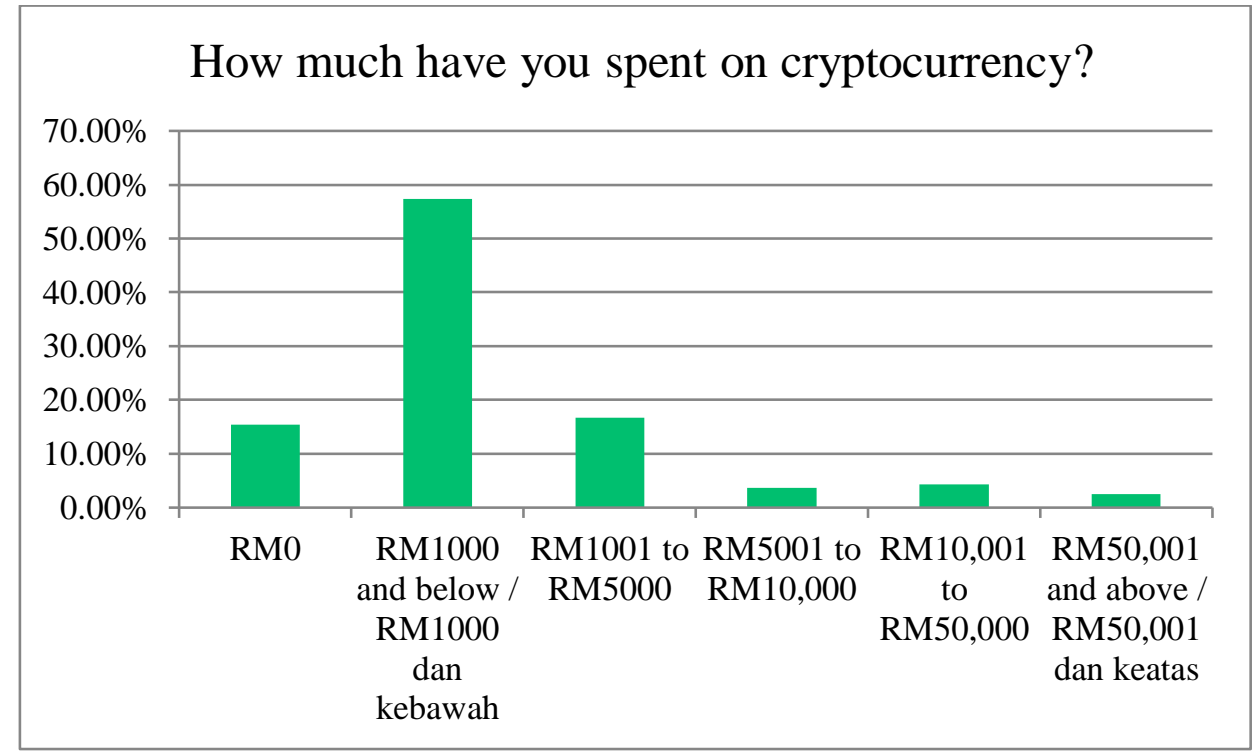

Figure 6: Amount Spent on Cryptocurrency

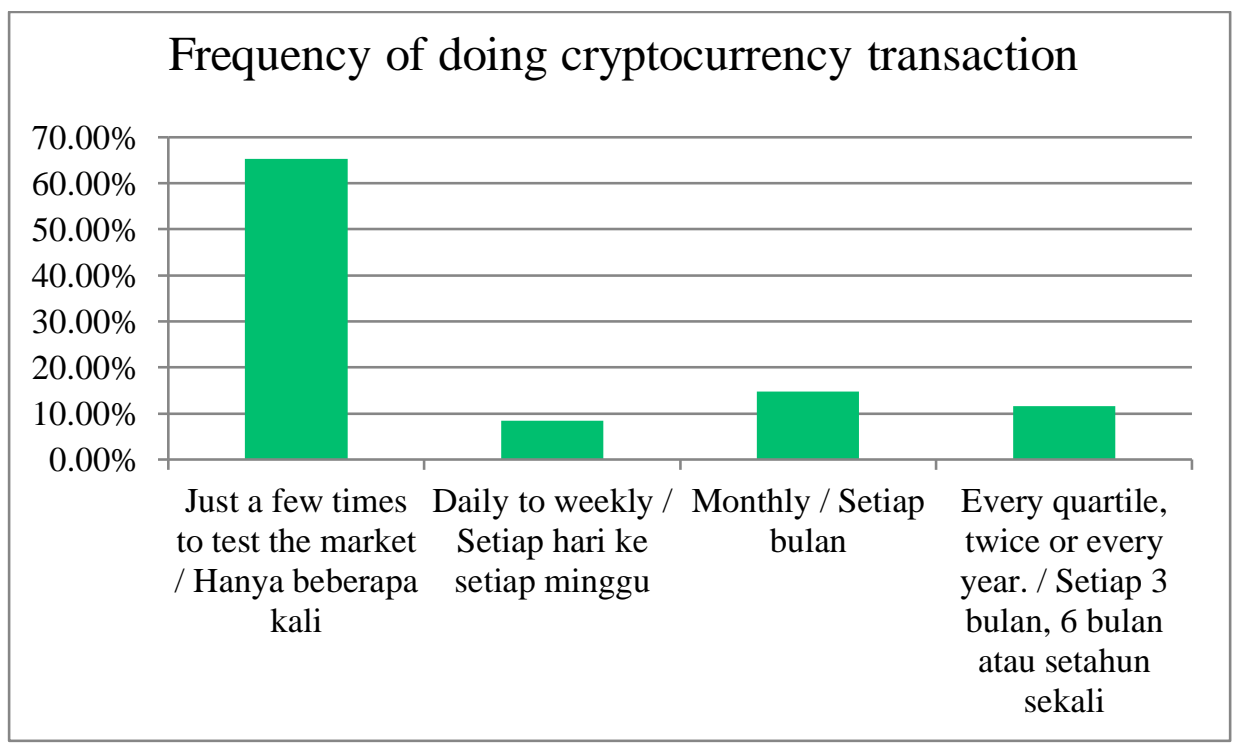

Figure 7: Frequency of Doing Cryptocurrency Transaction

More than 65 per cent of survey respondents only tried few times to just test the market. While 14.74 per cent monthly, 11.58 per cent every quartile, twice or every year and daily to weekly 8.42 per cent. This demonstrates that survey respondents do not invest a lot of money on cryptocurrencies. The next section discusses why there is not much spending on cryptocurrency and why the reluctancy is there.

Reasons for not spending money on cryptocurrency

Jurnal Ilmiah Al QALAM, Vol. 15, No. 2, Juli-Desember 2021 
As shown in Figure 8 below, the main reason for not spending on cryptocurrency is due to not being "technology savvy" with 24.97 per cent, the second one is 45.63 per cent Shariah concerns. Risk, Trust and Security concerns are the remaining choices taken with 15 to 16 per cent range. This shows that the scope of cryptocurrency within Muslim community can be improved by creating more Shariah awareness and technological awareness, and by reducing the risk, security and trust issues.

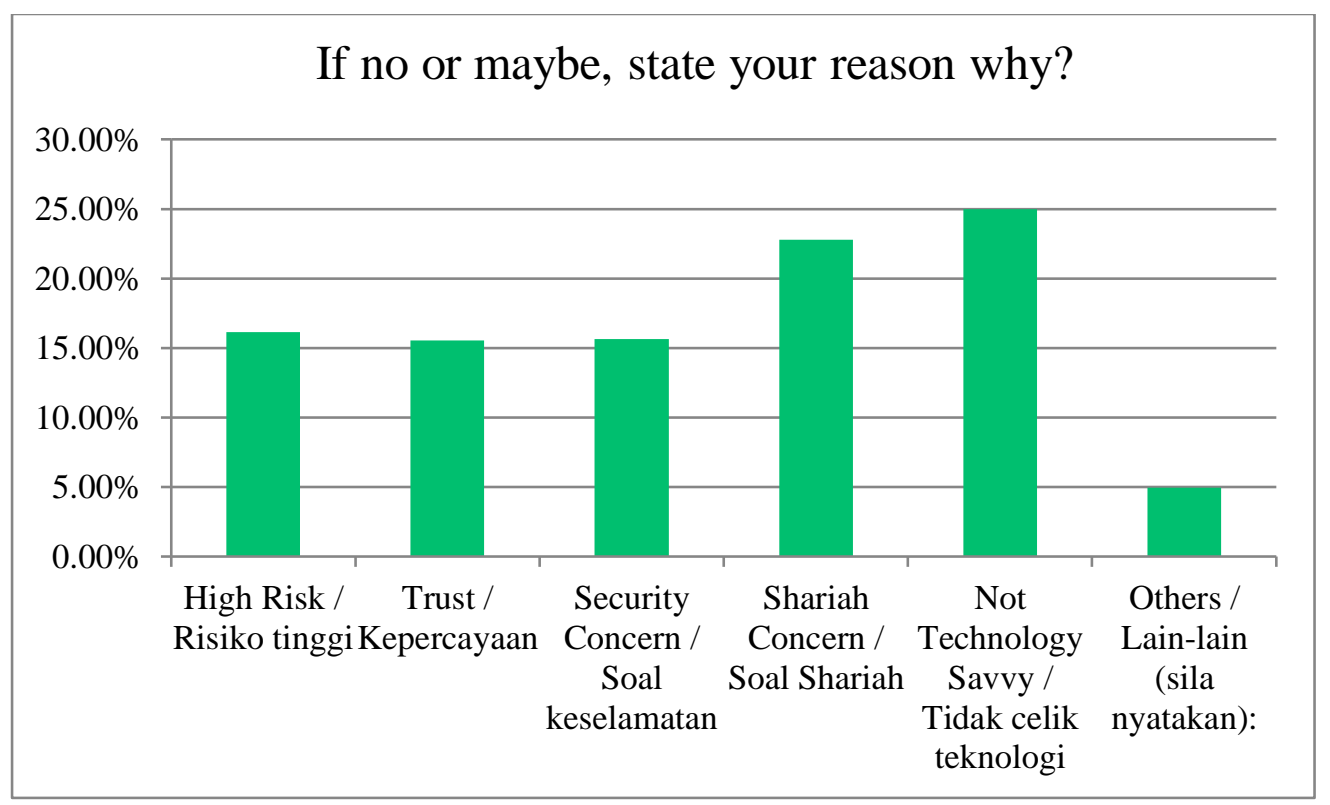

Figure 8: The reason to Not Spent, Invest or Traded Cryptocurrency

The other reasons stated by the respondents why the respondents do not invest in cryptocurrency are because of lack of confidence in the cryptocurrency market followed by limited awareness and information about how cryptocurrency functions and apprehension about possible scams. The technical reason can also be found when some of the respondent pointed out on the potential of manipulation in law, trading and the blockchain technology is still vulnerable to hacking. Another explanation for not investing in cryptocurrencies is that respondents were worried about the risks associated with it.

In summary, the respondents in Malaysia still have no confidence or lack of confidence in cryptocurrency and this can be justified by insufficient knowledge, information and awareness about cryptocurrency among Malaysians. From here, we can see there is a loophole that stop Malaysians from investing in cryptocurrency. The agency in charge can take this opportunity to raise awareness, clear the misconception and even educate Malaysians about cryptocurrency thus, boost up cryptocurrency market in Malaysia.

\section{Knowledge on Zakat and Its Applicability to Cryptocurrency}

In this section, the participants were tested based on the awareness of zakat on cryptocurrency. On the first question, 100\% were aware about zakat. As shown in Figure 9 below, majority of 85.47 per cent of participants responded that they paid zakat to state's 
zakat institution. Zakat collection centres from other state accounts to 17.7 per cent and 11.97 per cent paid zakat directly to Asnafs. This may be due to lack of trust to zakat collection centre, political reasons or the zakat payer may actually know that person (Asnaf) who are in need. Last but not least, 6.84 per cent paid zakat through other forms of zakat payment.

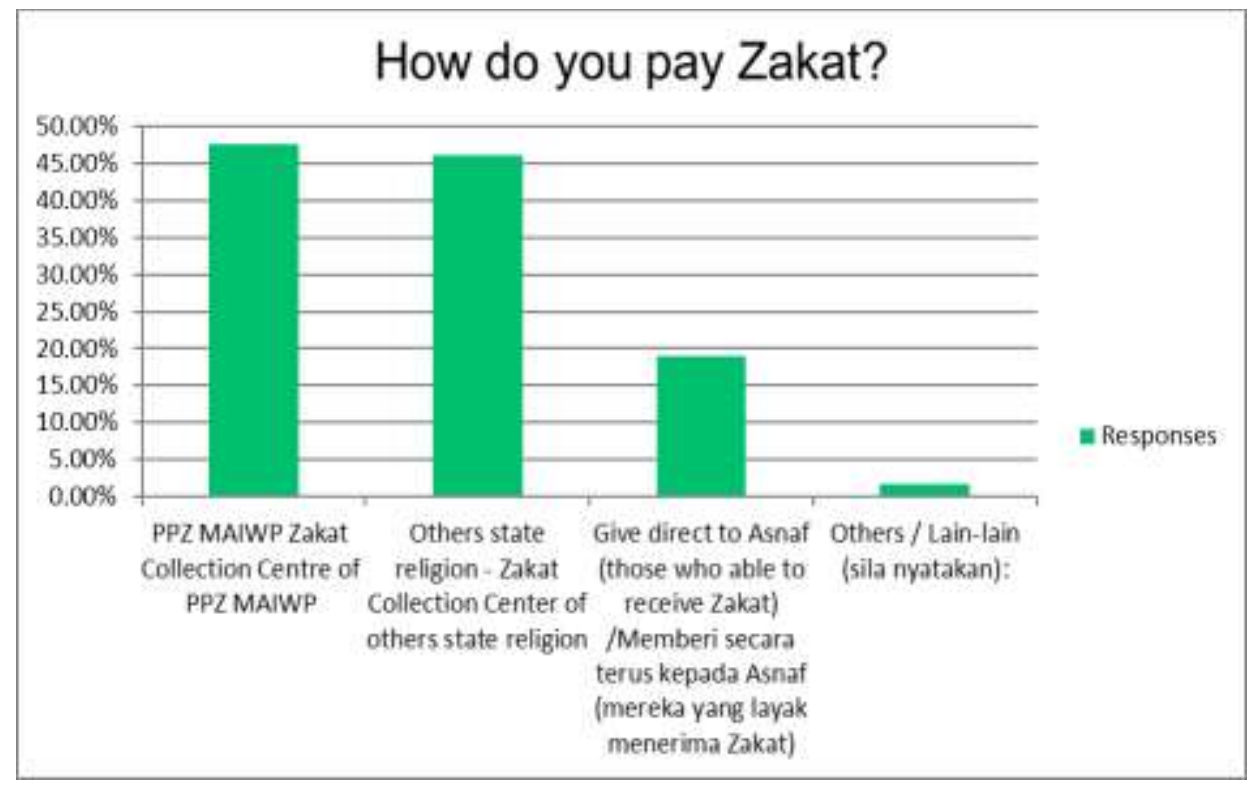

Figure 9: How Respondents Pay Zakat

To know about the obligation of zakat is one thing but to actually know that cryptocurrency need to be zakat is an important aspect to this project. Based on the Figure 10 below, majority of 78.27 per cent does not know that cryptocurrency need to be zakatable while 11.6 per cent are unsure about it. Only small portion of 10.12 per cent are aware about it. It is important that zakat collector to collaborate with crypto platform to give awareness and to educate Muslim user regarding the obligation of paying zakat on cryptocurrency. As small effort continuously will bring a tremendous change just like a butterfly effect. "Never doubt that a small group of thoughtful, committed citizens can change the world; indeed, it's the only thing that ever has," by Margaret Mead. 


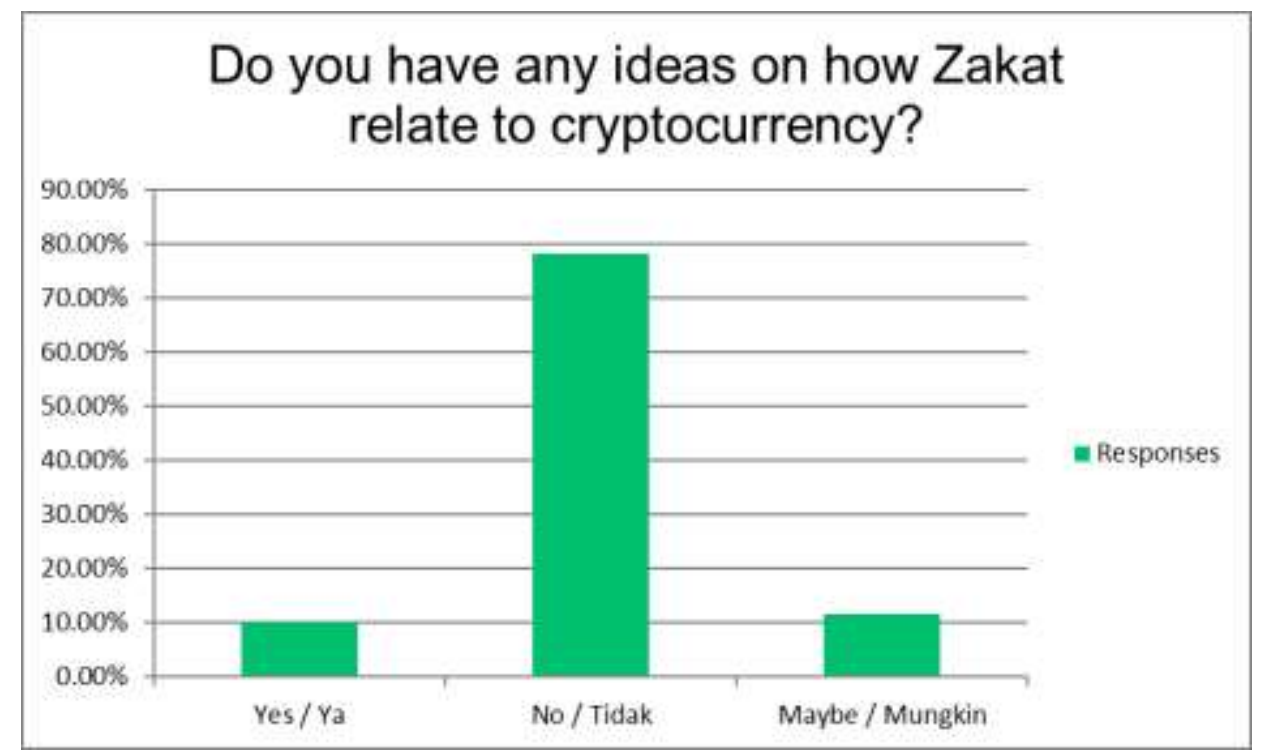

Figure 10: Opinion on How Zakat Related to Cryptocurrency

\section{Opinions of the Respondents on The "Need to Make Cryptocurrency Zakatable"}

In order to check the opinion and views of the respondents 3 minutes video of Cryptocurrency by International Monetary Fund (IMF) were shown. After the video, we asked if the views regarding cryptocurrency have changed with the new information received from the video. And the result showed that 52\% respondents said Yes or Maybe which shows that if people get more knowledge about cryptocurrency, then their views would change and are more likely to invest in crypto assets. Further, 57 per cent respondents answered that Yes or Maybe, that they might plan to invest or trade in cryptocurrency in the future.

\section{Has your view change after watching the video regarding to the topic above?}

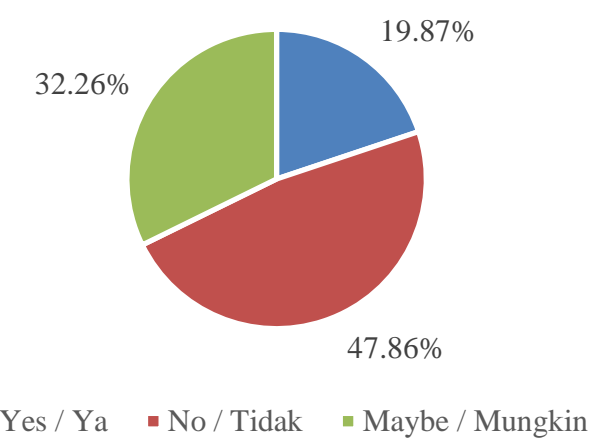

Figure 11: Respondents Views on Cryptocurrency After Watching Video Regarding Cryptocurrency 


\section{Do you have any plan to trade or invest on \\ Cryptocurrency?}

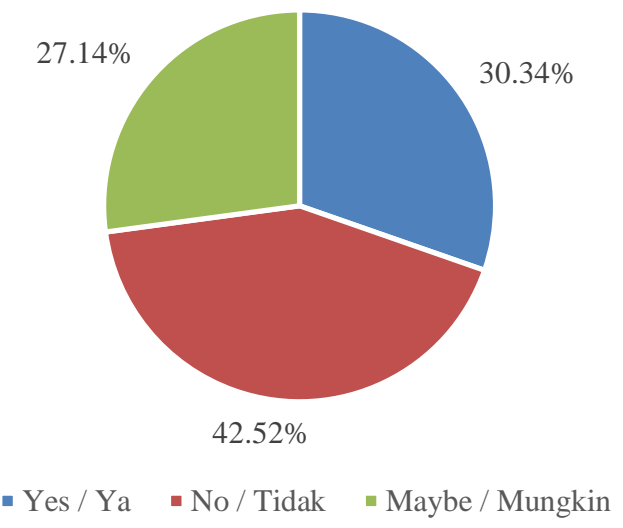

Figure 12: Respondents Plan to Trade or Invest on Cryptocurrency

According to an examination of public recommendations on "Cryptocurrency needs to be zakatable," it was discovered that the majority of the $30 \%$ of respondents agreed that zakat should be applied on cryptocurrencies. The respondents' reasons include that anything that generates an income is zakatable, and because cryptocurrencies are developing and individuals are gradually changing their assets to them, zakat should be implemented so that none of the assets are neglected by the zakat institution.

Another recommendation gauged from the survey is about the concern on the Shariah ruling on the legality to trade in cryptocurrencies. It happened that many of the respondents questioned the legality of trading in cryptocurrencies and more often than not, they referred to the Bayan Linnas issued by MAIWP in November 2018 stating that cryptocurrencies are impermissible therefore the zakat cannot be collected from cryptocurrencies since the sources are already impermissible. Besides, the other respondents were also suggesting the zakat institution to make it clear whether cryptocurrencies are permissible or not.

Moving on, it was discovered that some of the respondents had no knowledge of cryptocurrency. Some of them may be aware, but not in the specifics of how it works. As a result, it can be stated that Malaysians' awareness of cryptocurrency is still limited. Furthermore, the disinformation and myths around cryptocurrency must be dispelled so that there are no more difficulties that upset and confuse people. As a result, there is a need to educate and raise public knowledge of cryptocurrencies. In order to levy zakat on cryptocurrency, the Shariah judgement on legality must first be completed. Following that, respondents were concerned about the zakat calculation if it was going to be zakat-ed, and so they inquired for the zakat institution to come out with correct guidelines on the haul and nisab for the calculation of zakat for cryptocurrency.

\section{RECOMMENDATIONS}

Jurnal Ilmiah Al QALAM, Vol. 15, No. 2, Juli-Desember 2021 


\section{More Awareness is Needed}

It is highlighted that, despite the fact that a large number of respondents are aware of bitcoin, a smaller percentage of individuals actively invest in cryptocurrencies. As previously stated in the research, reasons for not spending include high risk, lack of confidence due to the prevalence of scammers, security issues, Shariah concerns, and being technologically challenged. According to the study results, $79 \%$ of respondents had never traded bitcoin prior to the video presentation. However, following the video, it was discovered that $57 \%$ of respondents are eager to spend bitcoin, while just $43 \%$ do not want to invest in cryptocurrencies. This demonstrates that when people get more knowledge, their opinions will most likely alter and they will invest in digital currencies. As a result, broad public awareness initiatives are critical, particularly for the following aspects: i) Shariah knowledge, ii) technology training, and iii) understanding of digital assets and currencies.

Furthermore, understanding of the zakat responsibility on cryptocurrency must be addressed. According to the survey, 78.27 percent of respondents have no understanding how zakat relates to cryptocurrencies. According to a spokesman from Tokenize, there is a lot of space for development in this market. Most essential, there is a need to raise public knowledge of bitcoin, as well as enhance technical literacy. Furthermore, as a first step in increasing knowledge of zakat on cryptocurrencies and the generation of wealth through bitcoin investment, the existing issue of Shariah concern by the public must be addressed. With that, it can be a good start to clarify the present situation of Shariah ruling from the MAIWP office in order to establish public trust in the use of cryptocurrencies. As a result, there is a need to raise knowledge about both the zakat duty on cryptocurrencies and the generation of wealth through cryptocurrency investing.

\section{Larger Acceptance and Usage of Cryptocurrency is Needed}

If zakat agencies connect into the world of digital assets, it will create a new and massive (in terms of value) zakat stream. As a result, the collection of zakat will grow, benefiting the Asnafs. However, in order to reap the full benefits of this, digital assets must be widely accepted and used. In addition, the present difficulties in such transactions must be remedied. For example, in order to eliminate scams, fraud, and illicit use of digital assets, an electronic way of identifying users is required. According to industry analysts, KYC and user identity are required for general adoption of digital assets. Furthermore, with greater acceptability, it would be easier to send bitcoin as zakat to the appropriate beneficiaries.

Encouraging the general population to invest in and utilise cryptocurrencies carries a big risk for them. However, the general public must recognise that risk is inherent, inescapable, and unavoidable in every investment. As with any danger, there is khatar (market risk) with bitcoin trading. The majority of the hazards connected with cryptocurrency are related to its volatility, and volatility should not be used to discourage people from utilising it. For the time being, it is unavoidable that there will be many risks, but according to a poll, consumers are prepared to accept the risk. According to the results of the study, 57.48 percent of participants want to invest in cryptocurrencies. 
Risks and uncertainties in the crypto sector will decrease as popularity grows and government regulation increases. When trade and market acceptability improve, gharar decreases, and when risk appetite is strong and risks become calculable, risk can be regulated, reducing uncertainty. It all comes down to how much danger a person is prepared to accept. From here, it is critical to educate consumers to recognise digital currency as one of the instruments in a high-risk investing portfolio. Despite the fact that it is significant risk, the nature of the investment can/should be identified. However, in this context, we would want to urge individuals in general to thoroughly comprehend and conduct study before making such an investment.

\section{Guideline for Shariah Compliant Cryptocurrency}

Digital assets/currencies are very new to the Malaysian market, in terms of how they function, how to invest in them, and the procedures involved. As it is not a regulated market, there are many forms of digital assets and currencies on the market, as well as diverse firms. People are unsure if it is Shariah-compliant or not. It would be ideal if the government could create a governance framework for digital assets. No blanket fatwa should be issued for digital assets as a whole since each sort of digital asset is unique in its own way. They should also be screened separately. Furthermore, because one of the respondents' concerns is the Shariah concerns related with digital assets, it is suggested that zakat agency commence the process of developing a Shariah screening process for digital assets, similar to the Shariah screening process for stocks. A Shariah screening method is required to determine which digital tokens/assets are halal and haram. A Shariah governance structure and a Shariah screening mechanism for digital assets must be implemented. A structure and regulation of this type would aid in reducing the risks related with fraud, security issues, trust difficulties, and Shariah concerns. Furthermore, this would establish the groundwork for the job of collecting zakat from digital asset transactions to begin.

\section{Zakat Institutions Can Look into Option of Accepting Cryptocurrency as Zakat}

There is certain institution which accept zakat/charity in cryptocurrency. Organizations such as Global Sadaqah and Blossom Finance assist in accepting cryptocurrency and facilitate to change Bitcoin to legal tender and distribute to recipients. It is advisable to zakat institution also to look into this spectrum and open their institution to the possibility of receiving zakat in cryptocurrency. In order to start the process, state's zakat institution should set the regulatory framework with industry and Shariah experts. As more institutions collecting bitcoin as Zakat, then collection would also increase. As said by Umar Munshi, Umar Munshi, Managing Director of Ethis Global, the parent company of GlobalSadaqah: "Blockchain has a lot of potential to increase the effectiveness of social finance. This is just the first step for us to integrate blockchain into the Islamic fintech 
ecosystem we are building. Another interesting area is blockchain-based notarizing of Waqf (Islamic endowments) documents and wills, among other things." 20

\section{CONCLUSION}

As cryptocurrencies gains popularity among providers, there may be a greater need for a more comprehensive range of Shariah-compliant goods and governance within Islamic financial marketplaces. As the number of Muslims who own cryptocurrencies grows, there is a greater need to understand how they might pay zakat on their holdings. When paying Zakat, Muslims must examine their 'Nisab' level as well as the techniques of paying zakat through digital investments. As the crypto market grows and matures, established financial institutions and Zakat-recipient organisations must be proactive in their approach and creation of mechanisms to accommodate new sorts of payments.

\section{REFERENCES}

Al-Auqof Al Kuwaitiyah. (1983) "al-Islamiyyah, al-Mausu'ah al-Fiqhiyah alKuwaitiyah." Kuwait: Dzat as-Salasil.

Abd Rahman, Ahmad Husni and Abdullah, Muhammad Furqan. (2021), Tinjauan Awal Aplikasi Hukum Zakat Ke Atas Matawang Kripto Dan Token Digital. Pusat Pungutan Zakat

Abidin, I. (1992). Radd al-Muhtār 'ala al-Dar al-Mukhtār. Dar al-Fikr.

Abu-Bakar, Mufti Muhammad. (2017). "Shariah Analysis of Bitcoin, Cryptocurrency and Blockchain."

Adam, Mufti Faraz. (2017). "Bitcoin: shariah compliant." Amanah Finance Consultancy 2017 (2017): 1-54. http://www.iefpedia.com/english/wpcontent/uploads/2017/12/Bitcoin-Shariah-Compliant-Mufti-Faraz-Adam.pdf

Al-Ghazali. (2004). Ihya 'Ulum al-Din. Dar al-Marifah.

Al-Haddad, H. (2017). Hukm Al-Ta'āmul Bi Al- 'Umlah Al-Elektrūniyyah Al-Musfirah: (AlBitkoin) wa akhowātihā https://dorar.net/article/1982/ Hukm Al-Ta'āmul Bi Al'Umlah Al-Elektrūniyyah Al-Musfirah: (Al-Bitkoin) wa akhowātihā

Allam, S. (2018). “Al-Bitkoin” Mufti Al-Jumhuriyyah yubayyin Hukm Al-Ta'āmul bi Al'Umlah Al-Elektrūniyyah. https://www.daralifta.org/ar/Viewstatement.aspx?sec=media\&ID=5617

Al-Qaradaghi, A. (2018). No. http://www.qaradaghi.com/Details.aspx?ID=3790

Al-Suyuti, Jalaulddin. (1983). "Al-Ashbah wa al-Naza'ir." Kairo: Dar al-Salâm (1983).

Bakar, M. D. (2018). Bitcoin: Mata Wang, Komoditi, Sekuriti atau Identiti Baru? Satu Perbincngan Minda Syariah (Bahagian II). http://coin.my/2018/01/16/bitcoinmatawang-komoditi-sekuriti-identiti-baru-bhgn-ii/

\footnotetext{
${ }^{20}$ Fintech News Malaysia. "GlobalSadaqah to Enable Zakat and Waqf Payments Using Bitcoin.” Accessed April 3, 2021. https://fintechnews.my/23658/blockchain/globalsadaqah-to-enable-zakat-and-waqf-paymentsin-bitcoin/
} 
Bank Negara Malaysia (2017). Making digital currencies transparent in Malaysia, Press Releases Ref. No. 12/17/13.

Fintech News Malaysia. "GlobalSadaqah to Enable Zakat and Waqf Payments Using Bitcoin.” Accessed April 2021. https://fintechnews.my/23658/blockchain/globalsadaqah-to-enable-zakat-andwaqf-payments-in-bitcoin/

Fintech News Malaysia."Luno Claims Crypto Exchange Top Spot in Malaysia with RM 827 Million in Transactions." Accessed April 3, 2021 https://fintechnews.my/25557/blockchain/luno-claims-crypto-exchange-top-spotin-malaysia-with-rm-827-million-transactions/

Fong, V. (2019). Meet the 56 Cryptocurrency Exchanges in Malaysia Registered with BNM. https://fintechnews.my/16980/blockchain/cryptocurrency-exchanges-inmalaysia-registered-bnm/

Illana Polyak. (2015). "Age and risk tolerance key to mastering asset allocation," CNBC, accessed April 3, 2021, https://www.cnbc.com/2015/06/10/age-and-risk-tolerancekey-to-mastering-asset-allocation.html

Islamic Relief Worldwide. (2019), Zakat. https://www.islamic-relief.org/zakat/ Liberto, Daniel. (2021), What is Zakat? https://www.investopedia.com/terms/z/zakat.asp

MN Paizin. (2014). Perlaksanaan Zakat Di Wilayah Persekutuan: Satu Pemerhatian Terhadap Operasi Kutipan \& Agihan Zakat. Jurnal Hadhari: An International Journal 6 (2), 97-111

MN Paizin \& Suhaili Sarif. (2016). Kemudahan Pembayaran Zakat: Tinjauan Di Wilayah Persekutuan dan Selangor. Labuan e-Journal of Muamalat and Society Vol. 10(2016), 66-76.

MN Paizin. (2017). Usage of Islamic Alms's Online Portal: Case Study on Pusat Pungutan Zakat (PPZ), Federal Territories of Malaysia. Intellectual Property Rights: Open Access, Vol.5, Issue.1:3.

MN Paizin. (2021). The Concept of Zakat on Income in Malaysia and Its Beginning of Implementation. Al-Kharaj: Jurnal Ekonomi, Keuangan \& Bisnis Syariah 3 (3), 417-436

National Zakat Foundation. (2021), What is Zakat. https://nzf.org.uk/about-zakat/what-iszakat/

Norton Rose Fulbright. (2015). "Deciphering cryptocurrencies: A global legal and regulatory guide." In Chapter 1: Introduction to cryptocurrencies, 1- 20.

Chris Morris. (2021). "The Future of Digital Currency," Nasdaq, February 12,2021, https://www.nasdaq.com/articles/the-future-of-digital-currency-2021-02-12

OECD (2019), Cryptoassets in Asia. Consumer attitudes, behaviours and experiences.

Pusat Pungutan Zakat. (n.d), Syarat Wajib Zakat. https://www.zakat.com.my/infozakat/syarat-wajib-zakat/

Dodik Siswantoro, Handika Rangga, and Aria Farah Mita. (2020). "The requirements of cryptocurrency for money, an Islamic view," Heliyon, 6(1), e03235. https://doi.org/10.1016/j.heliyon.2020.e03235 
Statista. (2017). Norway: ownership of cryptocurrency by age group 2017 Statista. [online] Available at: https://www.statista.com/statistics/807166/survey-on-ownership-ofcryptocurrency-in-norway-by-age-group/ [Accessed 4 Apr. 2021].

The Malaysian Reserve. "PPZ-MAIWP's zakat collection increases 11\% to RM756 mil." Accessed April 3, 2021, https://themalaysianreserve.com/2021/01/01/ppz-maiwpszakat-collection-increases-11-to-rm756-mil/ 